\title{
COULD OZONE TREATMENT BE A PROMISING ALTERNATIVE FOR OSTEOMYELITIS? AN EXPERIMENTAL STUDY
}

\section{O TRATAMENTO COM OZÔNIO PODE SER UMA ALTERNATIVA PROMISSORA PARA A OSTEOMIELITE? UM ESTUDO EXPERIMENTAL}

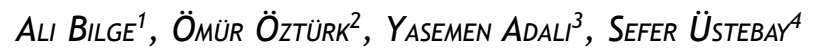 \\ 1. Department of Orthopedics and Traumatology, Kafkas University, Faculty of Medicine, Kars, Turkey. \\ 2. Department of Anesthesia and Reanimation, Kafkas University, Faculty of Medicine, Kars, Turkey. \\ 3. Department of Pathology, Kafkas University, Faculty of Medicine, Kars, Turkey. \\ 4. Department of Pediatrics, Kafkas University, Faculty of Medicine, Kars, Turkey.
}

\section{ABSTRACT}

Objective: The aim of the present study was to investigate the biochemical and histopathological impact of ozone treatment in an experimental model of osteomyelitis in rats. Methods: A total of 24 adult male Sprague-Dawley rats (3 months old, each weighing 300 to $400 \mathrm{~g}$ ) were randomly allocated into three groups. Group I $(n=8)$ served as a control and received no interventions or medications. In Group II ( $n=8)$, osteomyelitis was induced in the femur and no treatment was applied. Group III $(n=8)$ received intraperitoneal ozone treatment for 3 weeks after the formation of osteomyelitis in the femur. Serum samples were taken to assess total antioxidant capacity (TAC), protein carbonyl content (PCO), and lactate dehydrogenase (LDH). Bone specimens obtained from the femur were histopathologically evaluated for inflammation, necrosis, osteomyelitis, and abscess formation. Results: Serum TAC levels were notably higher $(p<0.001)$, while LDH levels were lower $(p=0.002)$ in Group III than Group II. No significant difference was detected between groups with respect to PCO level. Similarly, Group III displayed more favorable histopathological outcomes with respect to osteomyelitis $(p=0.008)$, inflammation $(p=0.001)$, necrosis $(p=0.022)$, and abscess formation $(p=0.022)$. Conclusion: Ozone may be a useful adjunct treatment for osteomyelitis. Further studies in animals and humans are needed to clarify and confirm these preventive effects, understand the underlying pathophysiology, and establish guidelines. Level of Evidence II; Prospective comparative study.

Keywords: Osteomyelitis/therapy. Ozone/adverse effects. Ozone/ therapeutic use.

\section{RESUMO}

Objetivo: O objetivo do presente estudo foi investigar o impacto bioquímico e histopatológico do tratamento de ozônio em modelo experimental de osteomielite em ratos. Métodos: Vinte e quatro ratos Sprague-Dawley machos adultos (3 meses de idade, pesando de 300 a $400 \mathrm{~g}$ ) foram alocados randomicamente em três grupos. 0 grupo I $(n=8)$ serviu como controle. No Grupo II $(n=8)$, o modelo de osteomielite experimental foi induzido no fêmur e não foi aplicado nenhum tratamento. O grupo III $(n=8)$ recebeu tratamento com ozônio intraperitoneal por 3 semanas depois da formação de osteomielite no fêmur. Foram coletadas amostras de sangue para avaliar a capacidade antioxidante total (CAT), a concentração da proteína carbonil (PCO) e da lactato desidrogenase $(L D H)$ no soro. As amostras do fêmur foram avaliadas por histopatologia quanto a inflamação, necrose, osteomielite e formação de abscesso. Resultados: Os níveis séricos de TAC foram notavelmente maiores ( $p<0,001$ ), enquanto os níveis de $L D H$ foram menores ( $p=0,002)$ no Grupo III em comparação com o Grupo II. Nenhuma diferença significativa foi detectada entre os grupos com relação ao nível de PCO. Do mesmo modo, o Grupo III apresentou resultados histopatológicos mais favoráveis para osteomielite $(p=$ $0,008)$, inflamação $(p=0,001)$, necrose $(p=0,022)$ e formação de abscesso $(p=0,022)$. Conclusão: O ozônio pode ser um tratamento adjuvante útil na osteomielite. Mais estudos com animais e com seres humanos são necessários para esclarecer e confirmar esses efeitos preventivos, compreender a fisiopatologia subjacente e estabelecer diretrizes. Nível de Evidência II; Estudo prospectivo comparativo.

Descritores: Osteomielite/terapia. Ozônio/efeitos adversos. Ozônio/ uso terapêutico.

Citation: Bilge A, Öztürk Ö, Adalı Y, Üstebay S. Could ozone treatment be a promising alternative for osteomyelitis? An experimental study. Acta Ortop Bras. [online]. 2018;26(1):67-71. Available from URL: http://www.scielo.br/aob.

\section{INTRODUCTION}

Osteomyelitis is an infection which may be accompanied by necrosis of the bone. Even after debridement, persistence of necrotic tissue may prevent blood from circulating and antibiotics from reaching necrotic tissue. This isolation from defensive and remedial mechanism may cause the process to become chronic. ${ }^{1}$ Treatment is based on eliminating the infection and maintaining ideal physiological function of the relevant area. High rates of recurrence,

All authors declare no potential conflict of interest related to this article.

Work conducted at the Şehitler Mah. 2. Kombine Binası Kafkas Üniversitesi Kampüsü Sağık Araştırma ve Uygulama Hastanesi Merkez|Kars.

Correspondence: Department of Orthopedics and Traumatology, Kafkas University, Faculty of Medicine, Kars, Turkey. alibilge498@hotmail.com 
increased medical costs, and long duration of disability are the principal therapeutic challenges. Even though sufficient surgical intervention, appropriate antibiotic regimen, and reconstruction of tissue architecture are the mainstays of treatment, optimal outcomes cannot always be achieved. ${ }^{2}$

Contemporary management of osteomyelitis consists of long-term administration of high-dose antibiotics, along with drainage of the purulent material. However, even this regimen may not always stop acute inflammation from progressing to a chronic, ongoing process. There is still debate on the duration of antibiotic treatment and time for surgical drainage. Enhancement of the host's defense system is important to eradicate infection. Therefore, local and systemic defense mechanisms should be supported to achieve therapeutic goals. ${ }^{2}$

Ozone is an oxidizing gas which can be synthesized by ultraviolet rays and is used as a disinfectant in the food and water industries. Despite its toxic potential, ozone may also serve as a pro-drug at controlled, non-toxic doses; it can help ameliorate ischemic injury in various tissues. ${ }^{3}$ Ozone exerts its beneficial effects by decreasing the levels of free oxygen radicals, inducing local migration of polymorphonuclear leukocytes, and promoting oxygen supply to injured tissues. ${ }^{3}$ Ozone increases the activity of leukocytes, and these cells may not function effectively when sufficient oxygen is not present in the medium. Furthermore, long-term use of ozone increases oxygen in the blood and may diminish the likelihood of allergic reactions. ${ }^{3}$

Since ozone can eradicate pathogenic factors, it may be useful to manage the high socioeconomic burden associated with chronic infections and diseases. Ozone may stimulate growth factors, control inflammatory processes, and elicit vascularization. The prolonged and challenging treatment of osteomyelitis leads researchers to investigate new therapeutic strategies; ${ }^{1}$ the purpose of the present study was to investigate the biochemical and histopathological impacts of ozone treatment in an experimental model of osteomyelitis in rats.

\section{METHODS}

\section{Experimental design}

This study was carried out in the experimental laboratory of our university after approval by the Kafkas University Animal Experimentation Ethics Committee.

The study adhered to the principles established in the National Institute of Health's Guide for the Care and Use of Laboratory Animals. The animals were fed a standard rat chow diet, and access to water and food was allowed ad libitum. Cages were kept at a temperature of $24 \pm 2{ }^{\circ} \mathrm{C}$ and humidity of $55 \pm 5 \%$ in a 12 hour light \& dark cycle. A total of 24 adult male Sprague-Dawley rats (3 months old, each weighing 300 to $400 \mathrm{~g}$ ) were randomly allocated into three groups. Group I $(n=8)$ served as a control and received no interventions or medications. In Group II ( $=8)$, osteomyelitis was induced in the femur and no therapeutics were applied. Group III $(n=8)$ received ozone treatment after osteomyelitis was induced in the femur.

\section{Surgical procedure}

The experimental model of osteomyelitis was induced by implanting discs containing pathogeneous S. aureus in the femur. These discs were prepared in the microbiology laboratory using a McFarland nephelometer, which permits the use of a solution with a known concentration of microorganisms. ${ }^{4}$

Inhaled anesthetics were administered using specially designed conical canine anesthesia masks. For all groups, sevoflurane was introduced at a rate of $2 \mathrm{~L} / \mathrm{min}$ together with $100 \%$ oxygen. The oxygen flow was set at a rate of $4 \mathrm{~L} /$ min using the anesthesia apparatus. The concentration of sevoflurane was adjusted according to respiratory pattern and heart rate. The same sevoflurane vaporizer was utilized for all rats.

Under general anesthesia and a sterile dressing, a $3 \mathrm{~cm}$ skin incision was made above the right lower hind limb. After the femoral bone was exposed, a fracture was formed on the distal diaphysis. Reduction of the fracture was accomplished with the retrograde application of thin tip $(80.5 \mathrm{~mm})$ Kirschner wire through the medulla after access from the knee joint. Discs containing $S$. aureus were placed onto the fracture zone to create an experimental model of osteomyelitis. (Figures 1 and 2) The operation was finished by suturing the layers in the anatomical plane. Group III received daily intraperitoneal ozone treatment $(2 \mathrm{ml}, 30 \mu \mathrm{g})$ during the follow-up period of 3 weeks. Groups I and II received no therapeutic interventions. At the end of this period, blood samples were collected from tail veins, and histopathological specimen were gathered by resecting bone tissue from fracture areas where the bacteria was inoculated. (Figures 3 and 4).

\section{Histopathological examination}

Bone tissue specimens were initially preserved in $10 \%$ phosphate buffered formalin before histopathological examination. These tissue samples were embedded in paraffin wax and sliced into 4 $\mathrm{mm}$ thick sections. All sections were stained with hematoxylin-eosin and examined under light microscopy (Olympus BX50; Olympus Optical Co. Ltd., Tokyo, Japan) by a blinded pathologist.

Bone tissue samples were evaluated for the presence of osteomyelitis, necrosis, and abscess formation. (Figures 5-9) Inflammation

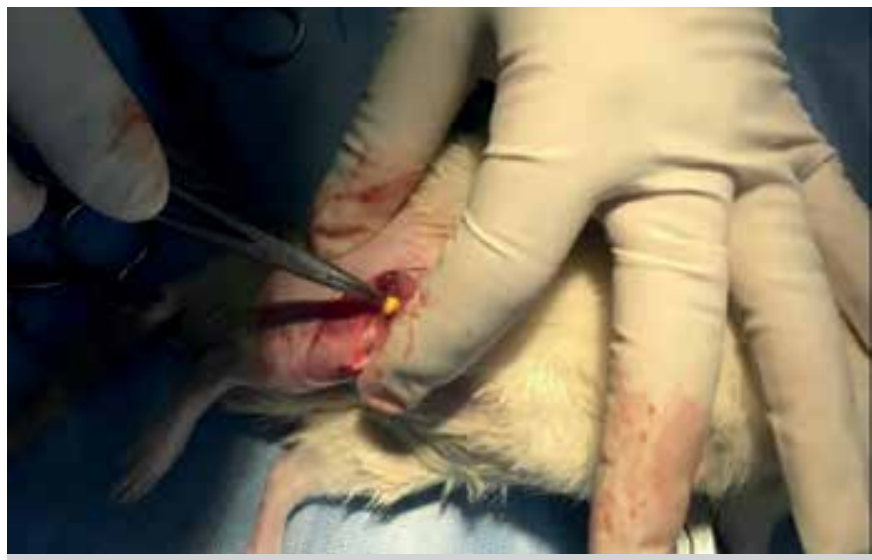

Figure 1. Inoculation of discs containing S. aureus onto femur to induce osteomyelitis.

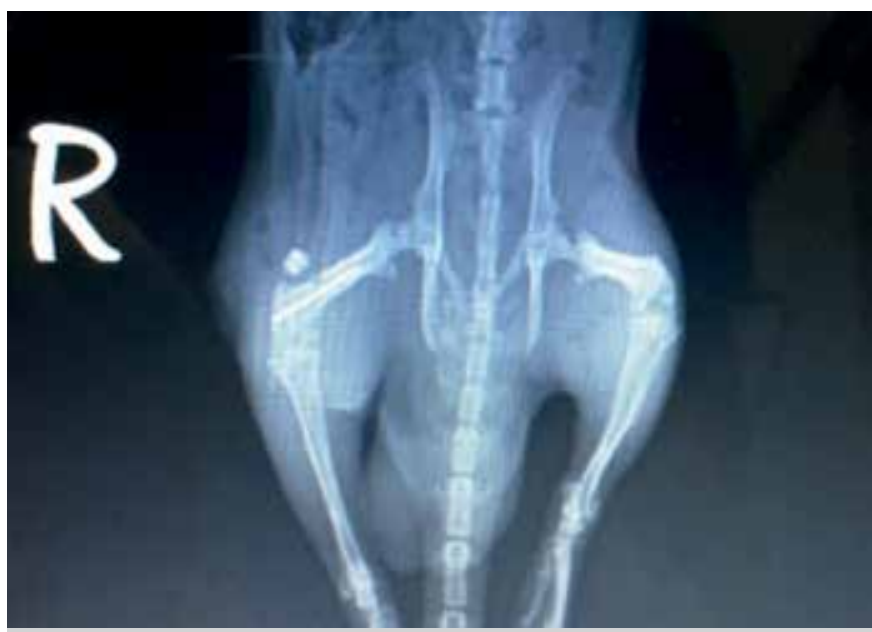

Figure 2. X-ray after inoculation with infective disc. 


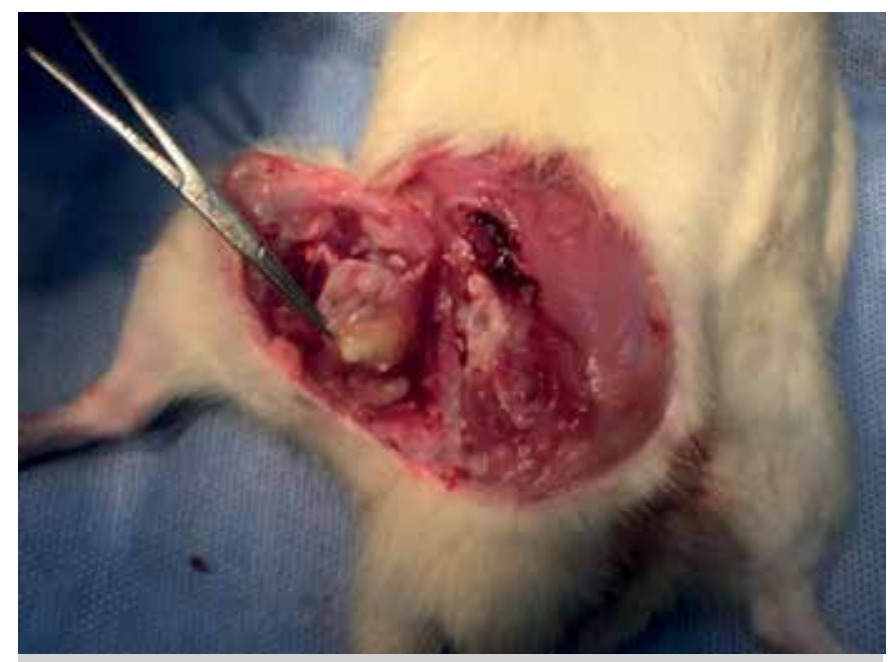

Figure 3. Dissection of the area with osteomyelitis after the 3-week study period.

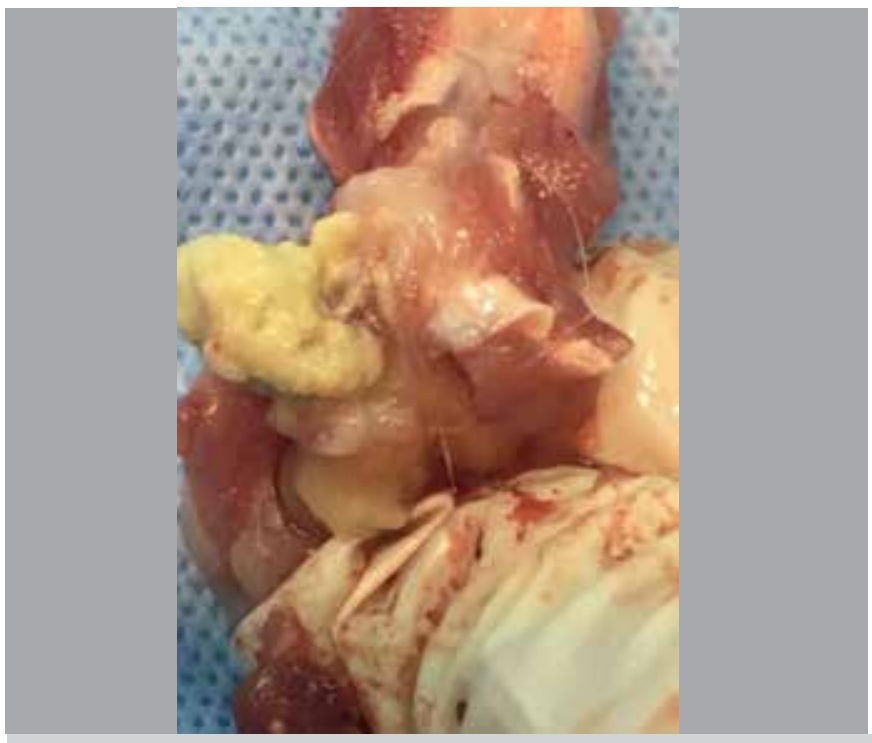

Figure 4. Bone specimen obtained from the site of osteomyelitis.

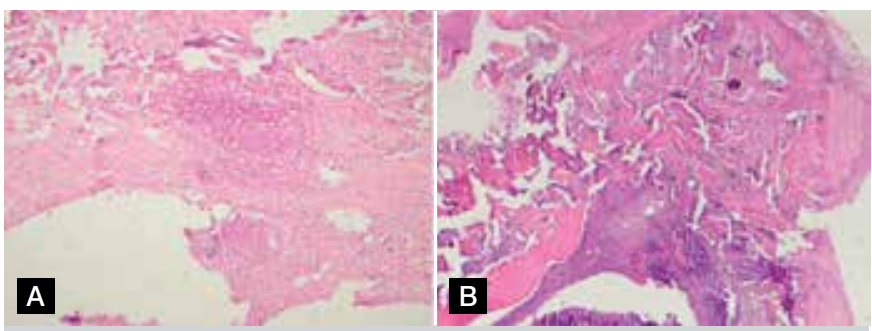

Figure 5. (A and B) Inflammation (left) and abscess cavity formations (right) (H\&E X100).

was graded using a scale based on a previously described method as 0 (no changes), 1 (focal, mild changes), 2 (multifocal, intermediate changes), or 3 (extensive, prominent changes). ${ }^{5,6}$

Serum studies

\section{Total antioxidant capacity (TAC)}

Total antioxidant capacity was measured using an autoanalyzer machine (Selectera XL, Holland) and commercially available kits based on the colorimetric method. ${ }^{7}$

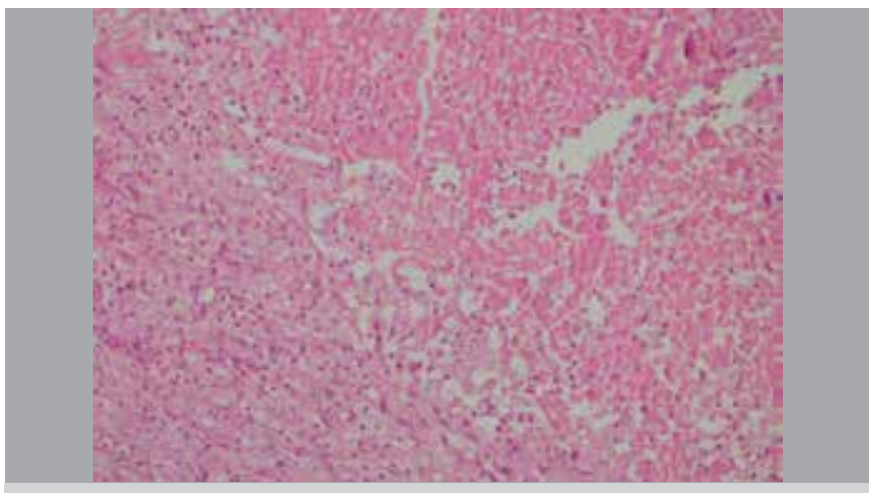

Figure 6. Areas of necrosis can be seen clearly in the specimen (H\&EX200).

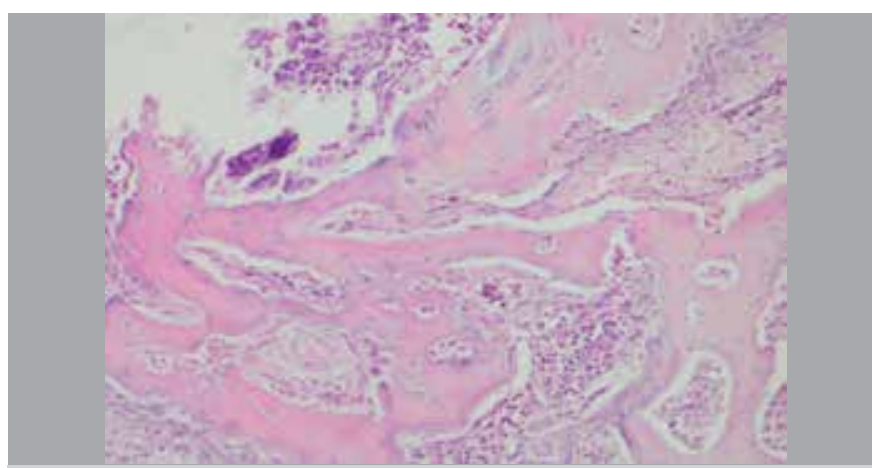

Figure 7. Mild degree of inflammation (H\&E X 200).

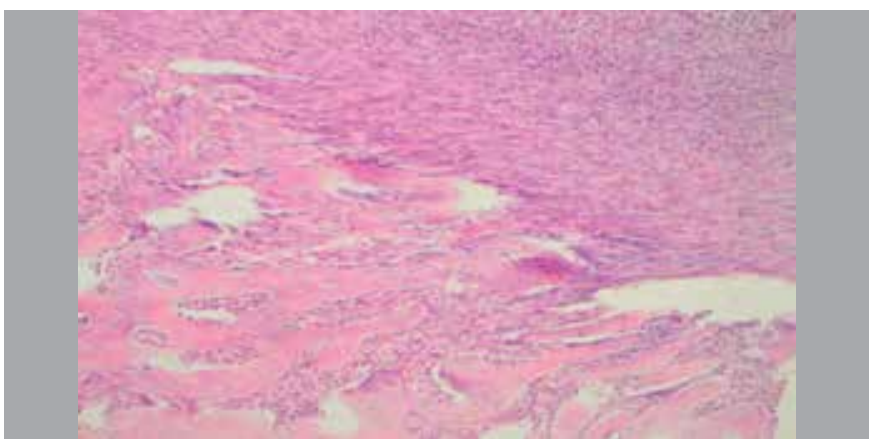

Figure 8. Moderate degree of inflammation (H\&E X 100).

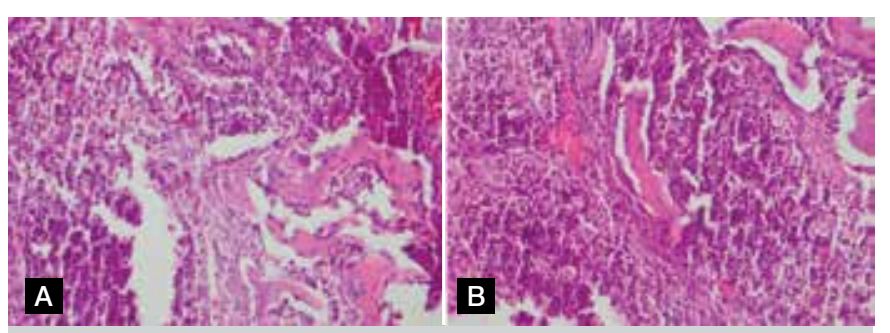

Figure 9. ( $A$ and $B)$ Areas demonstrating severe inflammation (H\&EX 200).

\section{Protein carbonyl content (PCO)}

A spectrophotometric method was utilized to evaluate PCO, as described in the relevant literature. ${ }^{8} \mathrm{PCO}$ reacts with 2,4-dinitrophenylhydrazine (DNPH) to generate chromophoric dinitrophenylhydrazones. A $0.5 \mathrm{ml}(1-2 \mathrm{mg})$ sample was added to an equal volume of $10 \mathrm{mM}$ DNPH in $2 \mathrm{~N} \mathrm{HCl}$ and incubated for 1 hour. After shaking the mixture intermittently at room temperature, a corresponding blank 
was formed by adding only $2 \mathrm{~N} \mathrm{HCl}$ to the sample. After incubation, the mixture was precipitated with $10 \%$ trichloroacetic acid and centrifuged. The precipitate was washed twice with ethanol:ethyl acetate (1:1) and finally dissolved in $1 \mathrm{ml}$ of $6 \mathrm{M}$ guanidine $\mathrm{HCl}$, centrifuged at low speed, and the supernatant was read at 366 $\mathrm{nm}$. The difference in absorbance between the DNPH-treated and $\mathrm{HCl}$-treated samples was determined and expressed as nmoles of carbonyl groups per mg of protein, using the molar extinction coefficient of DNPH, e $=22.000 \mathrm{mM}^{-1} \mathrm{~cm}^{-1}$.

\section{Lactate dehydrogenase (LDH) level}

The level of LDH was assayed spectrophotometrically by standard procedures using an automated analyzer (OpeRA, Bayer, USA). ${ }^{9}$

\section{Outcome parameters}

Three experimental groups were compared for three biochemical parameters and four histopathological variables. The biochemical parameters consisted of serum levels of TAC, $\mathrm{PCO}$, and $\mathrm{LDH}$, and the histopathological variables were osteomyelitis, inflammation, necrosis, and abscess formation. The existence and degree of inflammation was scaled as none, mild, moderate or severe. The presence of osteomyelitis, necrosis, and abscess formation was also noted.

\section{Statistical analysis}

The data were analyzed using IBM Statistical Package for Social Sciences Statistics 20 software (SPSS Inc., Chicago, IL, USA). Normal distribution of biochemical variables was assessed with the Lilliefors corrected Kolmogorov-Smirnov test. Serum levels of TAC and PCO displayed normal distribution, and comparison of their levels between groups was performed using ANOVA (post-hoc Bonferroni test). Kruskal-Wallis variance analysis (post-hoc Mann-Whitney $U$ test, with a revised p-value for statistical significance) was used to evaluate serum LDH levels (Mann-Whitney $U$ test was based on a new $p$-value of $0.05 / 3=0.016$ for LDH levels). The chi-square test was used to analyze the qualitative data. The level of significance was $p<0.05$ for all variables except for serum LDH levels.

\section{RESULTS}

Serum levels of TAC, PCO and LDH are shown in Table 1. TAC was notably different between groups $(p<0.001)$, while no remarkable difference was seen in PCO $(p=0.273)$. TAC differed between Groups I and II $(p<0.001)$ and Groups I and III $(p=0.001)$. On the other hand, TAC in Groups II and III did not differ significantly $(p=0.372)$. PCO content did not differ between Groups I and II $(p=0.393)$, Groups I and III ( $p=1.000)$, or Groups II and III $(p=0.668)$.

Table 1. Levels of total antioxidant capacity (TAC), protein carbonyl content (PCO), and lactate dehydrogenase (LDH) in 3 experimental groups.

\begin{tabular}{|c|c|c|c|c|}
\hline \multirow{2}{*}{ Variable } & \multicolumn{3}{|c|}{ Group } & \multirow{2}{*}{ p-value } \\
\hline & I & II & III & \\
\hline TAC & 3.570 .39 & 1.470 .71 & 2.030 .91 & $<0.001^{*}$ \\
\hline PCO & $\begin{array}{lll}68.36 & 0.47\end{array}$ & 77.4918 .11 & 70.194 .63 & 0.273 \\
\hline $\mathrm{LDH}$ & 1067.2568 .34 & 1732.0049 .83 & 1553.38211 .62 & $0.002^{*}$ \\
\hline
\end{tabular}

There was a noteworthy difference between serum LDH levels in all three groups ( $p=0.002)$, between Groups I and II $(p=0.010)$, and between Groups I and III ( $<<0.001)$. On the other hand, Group II and Group III had similar serum LDH levels $(p=0.161)$.

The chi-square test was used to analyze the histopathological parameters; the results are shown in Table 2. Statistically significant differences were seen between all three groups $(p<0.05)$ for the frequency of osteomyelitis $(p=0.008)$, inflammation $(p=0.001)$, necrosis $(p=0.022)$, and abscess formation $(p=0.022)$. Since expected values below 5 were seen in more than $20 \%$ of the cells in the tables, interpretations can reliably be made on a descriptive basis. Conclusions can be more accurately drawn for data presented in multicellular tables, such as degree of inflammation.

\section{DISCUSSION}

The current trial assessed the biochemical and histopathological impacts of ozone treatment in an experimental model of osteomyelitis in rats. Our results indicated that ozone treatment may enhance and improve TAC against osteomyelitis. It may consequently attenuate the deleterious effects of oxidative stress, and therefore may be a promising alternative for treating osteomyelitis. Further clinical and experimental trials are needed to clarify the role of oxidative stress in developing osteomyelitis, determine the efficacy of ozone treatment, and establish guidelines.

The beneficial effects of ozone treatment for osteomyelitis may involve several mechanisms: direct antibacterial and antiseptic impacts, improved tissue perfusion and oxygenation, and anti-inflammatory effects together with promotion of wound healing. ${ }^{1}$

Administering ozone treatment after osteomyelitis seems to ameliorate unfavorable histopathological alterations such as necrosis, abscess formation, inflammation, and osteomyelitis. The lack of difference in PCO levels between the groups serves as a reminder that oxidative stress injury may occur by a different mechanism in osteomyelitis. The beneficial impacts of ozone in osteomyelitis may be associated with activation of antioxidant mechanisms. ${ }^{10}$ A multidisciplinary approach may provide a more effective option for managing the complex biochemical and histopathological outcomes of osteomyelitis. Ozone treatment may affect different steps of the pathophysiological reactions involved in osteomyelitis. Dose, duration, and timing of ozone treatment may have important clinical implications for its use against osteomyelitis.

Some authors have suggested that oxidative stress can be reduced by enhancing local antioxidant systems and increasing endogenous capacity for reactive oxygen species (ROS) scavenging. ${ }^{11}$

Ozone treatment has distinct features and remarkable potential for treating various conditions in medical practice. Ozone has antimicrobial, immunomodulatory, anti-inflammatory, anti-hypoxic and hemostatic activities. These beneficial effects may be utilized to overcome the chronic refractory course of osteomyelitis and eliminate the resistance of the disease to conventional treatment. In the medical literature, hyperbaric oxygen treatment has been shown to improve the host response by creating a more favorable microenvironment for leukocyte activity, neovascularization, and

Table 2. Histopathological parameters (osteomyelitis, inflammation, necrosis and abscess formation) in 3 experimental groups.

\begin{tabular}{|c|c|c|c|c|c|c|c|c|c|c|}
\hline \multirow{3}{*}{ Group } & \multicolumn{10}{|c|}{ Variables } \\
\hline & \multicolumn{2}{|c|}{ Osteomyelitis } & \multicolumn{4}{|c|}{ Inflammation } & \multicolumn{2}{|c|}{ Necrosis } & \multicolumn{2}{|c|}{ Abscess } \\
\hline & - & + & None & Mild & Moderate & Severe & - & + & - & + \\
\hline I & $8(100 \%)$ & 0 & 8 & 0 & 0 & 0 & $8(100 \%)$ & 0 & $8(100 \%)$ & 0 \\
\hline II & $2(25 \%)$ & $6(75 \%)$ & 0 & 0 & $4(50 \%)$ & $4(50 \%)$ & $3(37.5 \%)$ & $5(62.5 \%)$ & $3(37.5 \%)$ & $5(62.5 \%)$ \\
\hline III & $5(62.5 \%)$ & $3(37.5 \%)$ & $3(37.5 \%)$ & 0 & $4(50 \%)$ & $1(12.5 \%)$ & $6(75 \%)$ & $2(25 \%)$ & $6(75 \%)$ & $2(25 \%)$ \\
\hline p-value & \multicolumn{2}{|c|}{$0.008^{\star}$} & \multicolumn{4}{|c|}{$0.001^{*}$} & \multicolumn{2}{|c|}{$0.022^{*}$} & \multicolumn{2}{|c|}{$0.022^{*}$} \\
\hline
\end{tabular}

Legend: * $=$ statistically significant. 
resorption of sequestrum. ${ }^{2}$ Our preliminary results demonstrated that ozone treatment might provide similar favorable therapeutic outcomes by reducing inflammation, necrosis and abscess formation. Mader et al. ${ }^{12}$ have shown that hyperbaric oxygen alone was as effective as antibiotics in treating experimental Staphylococcus aureus osteomyelitis. On the other hand, the best results were achieved by combined use of hyperbaric oxygen and antibiotics. To the best of our knowledge, the current study is the first experimental trial to evaluate the biochemical and histopathological impacts of ozone treatment in osteomyelitis. The search for the ideal preventive regimen must focus on investigating the effectiveness, safety, and optimization of combination treatment protocols. Our findings consequently may provide novel insights about preventive and therapeutic alternatives to treat osteomyelitis.

The limitations of the present study involve the experimental design, the complexity of counteracting oxidants and antioxidant substances in biological systems, and the lack of standardization for histopathologic data. On the other hand, simultaneous assessment of biochemical and histopathologic markers constitute an important strength of our study.

\section{CONCLUSION}

Our results demonstrated that ozone treatment may alleviate the deleterious biochemical and histopathological effects of osteomyelitis by enhancing antioxidant mechanisms and decreasing oxidative stress. Even though ozone treatment yielded promising results for osteomyelitis, the need for surgical debridement and antibiotic treatment should not be ignored. Ozone treatment must instead be considered a useful and effective adjunct to conventional treatment in selected cases. Further experimental and clinical trials are needed to clarify and confirm these preventive effects, understand the underlying pathophysiology, and establish guidelines.

AUTHORS' CONTRIBUTIONS: Each author made significant individual contributions to this manuscript. AB (0000-0002-8277-8697)* wrote and reviewed the article and performed the surgeries; $\mathrm{OO}$ (0000-0003-2270-2778** performed the surgeries, analyzed the data, and wrote the article; SU (0000-00031507-5921** performed the statistical analysis, participated in the surgeries, and reviewed the article; YA (0000-0002-8004-7364)* analyzed the slides and conducted the pathological data analysis. * ORCID (Open Researcher and Contributor ID).

\section{REFERENCES}

1. Dastan SA, Masoodi H, Salehi A. Use of ozone to treat wounds. Cumhuriyet Sci J. 2015;36(6):1365-73.

2. Chen CE, Ko JY, Fu TH, Wang CJ. Results of chronic osteomyelitis of the femur treated with hyperbaric oxygen: a preliminary report. Chang Gung Med J. 2004;27(2):91-7.

3. Das S. Application of ozone therapy in dentistry. Indian J Dental Adv. 2011;3:538-42

4. Bollela VR, Sato DN, Fonseca BA. McFarland nephelometer as a simple method to estimate the sensitivity of the polymerase chain reaction using Mycobacterium tuberculosis as a research tool. Braz J Med Biol Res. 1999;32(9):1073-6.

5. Gulmen S, Kiris I, Narin C, Ceylan BG, Mermi B, Sutcu R, et al. Tezosentan reduces the renal injury induced by abdominal aortic ischemia-reperfusion in rats. J Surg Res. 2009;157(1):e7-e13.

6. Tiemann A, Hofmann GO, Krukemeyer MG, Krenn V, Langwald S. Histopathological Osteomyelitis Evaluation Score (HOES) - an innovative approach to histopathological diagnostics and scoring of osteomyelitis. GMS Interdiscip
Plast Reconstr Surg DGPW. 2014;3:Doc08. doi: 10.3205/iprs000049.

7. Atashpour S, Kargar Jahromi H, Kargar Jahromi Z, Zarei S. Antioxidant effects of aqueous extract of Salep on Paraquat-induced rat liver injury. World J Hepatol. 2017;9(4):209-216.

8. Reznick AZ, Packer L. Oxidative damage to proteins: spectrophotometric method for carbonyl assay. Methods Enzymol. 1994;233:357-63.

9. Işeri SO, Sener G, Yüksel M, Contuk G, Cetinel S, Gedik N, et al. Ghrelin against alendronate-induced gastric damage in rats. J Endocrinol. 2005;187(3):399-406.

10. Stübinger S, Sader R, Filippi A. The use of ozone in dentistry and maxillofacial surgery: a review. Quintessence Int. 2006;37(5):353-9.

11. Seidler V, Linetskiy I, Hubálková H, Stanková H, Smucler R, Mazánek J. Ozone and its usage in general medicine and dentistry. A review article. Prague Med Rep. 2008;109(1):5-13.

12. Mader JT, Hicks CA, Calhoun J. Bacterial osteomyelitis. Adjunctive hyperbaric oxygen therapy. Orthop Rev. 1989;18(5):581-5. 
In the article entitled "COULD OZONE TREATMENT BE A PROMISING ALTERNATIVE FOR OSTEOMYELITIS? AN EXPERIMENTAL STUDY" authored by Ali Bilge, Ömür Öztürk, Yasemen Adali, Sefer Üstebay, published in Revista Acta Ortopédica Brasileira (ACTA) vol.26 n 1, 2018, page 67, DOl: http://dx.doi.org/10.1590/1413-785220182601179926, by request of the authors.

Where it reads: Review Article

Read: Original Article 